\title{
Keragaan Produksi Kentang G2 Genotipe IPB Asal Stek dan Umbi di Garut Jawa Barat
}

\section{Potato G2 Yield Performance of IPB Genotypes from Cutting and tuber at Garut Jawa Barat}

\author{
Neng Neni, Awang Maharijaya* dan Muhamad Syukur \\ Departemen Agronomi dan Hortikultura, Fakultas Pertanian, Institut Pertanian Bogor(Bogor Agricultural \\ University) Jalan Meranti, Kampus IPB Dramaga, Bogor 16680, Indonesia \\ Telp. \& Faks.021-8629353 email: agronipb@indo.net.id \\ *Penulis untuk korespondensi : awangmaharijaya@ipb.ac.id
}

Disetujui 20 Agustus 2018 / Published online 3 September 2018

\begin{abstract}
Common potato consumption and number of human population has increased, but the production decrease in 2015, which need new common potato high yield variety. Bogor Agricultural University created new potato genotypes by named PKHT-2, PKHT-3, PKHT-4, PKHT-6, PKHT-9, PKHT-10, and PKHT-12. Farmers have been using tubers seed from previous crops. Seed usage continously caused the potato production decrease, which needed alternative propagation technique in the field. This study aimed to getgenotype from single node cutting with the highest $G 2$ production performance and compared potato production between single node cutting and seed tuber. This research was conducted at the Tambakbaya village, Cisurupan and Margamulya village, Cikajang, Garut in February-July 2017. The first experiment used single node cutting genotype PKHT-2, PKHT-3, PKHT-4, PKHT-6, PKHT-9, PKHT-10, PKHT-12, Atlantik, Granola, Medians dan Intan. Second experiment used single node cutting and tuber seed genotype PKHT-4, Intan dan Medians. The result showed that production performance from single node cut affected by genotype. PKHT-6 genotype highest production performance $\left(18,32\right.$ ton $\left.\mathrm{ha}^{-1}\right)$ than another genotypes and control varieties. Three genotypes in second experiment used tuber propagation is PKHT-4, Intan, and Medians had higher yield potential than the plant from the single node cutting. PHKT-4 plant from tuber seed had yielded potential higher (17,00 ton $\left.\mathrm{ha}^{-1}\right)$ than control varieties.
\end{abstract}

Keyword: genotypes, production, single node cutting

ABSTRAK

Konsumsi kentang terus meningkat seiring meningkatnya penduduk, namun total produksinya mengalami penurunan pada tahun 2015, maka diperlukan usaha memperoleh varietas yang berproduktivitas tinggi. Institut Pertanian Bogor telah merakit genotipe kentang yaitu PKHT-2, PKHT-3, PKHT-4, PKHT-6, PKHT-9, PKHT-10, dan PKHT-12. Petani umumnya menggunakan benih dari hasil panen sebelumnya. Benih yang digunakan secara terus menerus dapat menyebabkan rendahnya produksi, maka perlu adanya alternatif teknik perbanyakan di lapang. Penelitian ini bertujuan untuk mendapatkan genotipe IPB asal stek buku tunggal dengan keragaan produksi G2 tertinggi dan membandingkan hasil produksi kentang antara tanaman yang berasal dari bahan tanam stek buku tunggal dengan umbi di lapang. Penelitian dilaksanakan pada Februari-Juli 2017 di Desa Tambakbaya, Kecamatan Cisurupan dan Desa Margamulya, Kecamatan Cikajang, Kabupaten Garut. Percobaan pertama menggunakan stek buku tunggal genotipe PKHT-2, PKHT-3, PKHT-4, PKHT-6, PKHT-9, PKHT-10, PKHT-12, Atlantik, Granola, Medians dan Intan. Percobaan kedua menggunakan bahan tanam stek buku tunggal dan umbi dari genotipe PKHT-4, Intan dan Medians. Hasil penelitian menunjukan keragaan produksi pada bahan tanam stek buku tunggal dipengaruhi oleh genotipe. Genotipe PKHT-6 menghasilkan keragaan produksi dan hasil tertinggi dibanding genotipe maupun varietas pembanding yaitu 18,32 ton ha $^{-1}$. Ketiga genotipe pada percobaan kedua menggunakan bahan tanam umbi yaitu PKHT-4, Intan dan Medians menghasilkan potensi hasil lebih tinggi dibandingkan dengan tanaman genotipe yang sama asal stek buku tunggal. Tanaman PKHT-4 asal umbi menghasilkan potensi hasil lebih tinggi dibandingkan varietas pembandingnya yaitu 17,00 ton ha ${ }^{-1}$.

Kata kunci: genotipe, produksi, stek buku tunggal 


\section{PENDAHULUAN}

Kentang merupakan sayuran batang yang kaya akan vitamin $\mathrm{C}$, karbohidrat dan mineral, namun menghasilkan protein dan provitamin A yang rendah. Kentang dapat dimanfaatkan sebagai sayuran, selain itu kentang juga dapat dimanfaatkan sebagai pengganti nasi (Zulkarnain, 2013). Kebutuhan kentang di Indonesia semakin meningkat seiring dengan meningkatnya jumlah penduduk (Samadi, 2007). Kebutuhan kentang dari tahun 2014-2015 mengalami peningkatan sebesar 57,12\%. Konsumsi kentang tahun 2015 menurut hasil Survey Sosial Ekonomi Nasional (SUSENAS) sebesar 2,29 kg per kapita (Kementan, 2016a). Peningkatan konsumsi tersebut tidak diimbangi dengan produksi kentang pada tahun yang sama. Berdasarkan data Kementerian Pertanian (2016b) produksi kentang pada tahun 2014 menurun sebesar $48 \%$ pada tahun 2015, dari 1,3 juta ton menjadi 1,2 juta ton. Penurunan produksi dapat disebabkan oleh menurunnya luas panen kentang. Berdasarkan data Kementerian Pertanian (2016c) luas panen pada tahun 2015 mengalami penurunan sebesar 12,20\% dari luas panen tahun sebelumnya. Luas panen kentang tahun 2015 hanya 66,98 ha.

Varietas merupakan hal yang perlu mendapatkan perhatian dalam usaha peningkatan produksi kentang. Kentang yang sangat diminati petani Indonesia adalah varietas Atlantik (introduksi dari Amerika Serikat) dan Granola L (introduksi dari Jerman Barat). Varietas Altantik menghasilkan potensi hasil sekitar 8-20 ton ha ${ }^{-1}$ dan umur panen genjah 100 hari setelah tanam. Apabila digoreng umbinya kering dan tidak berwarna, sehingga sangat cocok untuk dijadikan keripik (Keputusan Menteri Pertanian, 2000). Varietas Granola menghasilkan potensi hasil 26,5 ton ha $^{-1}$, umur panen genjah $100-15$ hari setelah tanam, dan baik untuk kentang meja atau sayur (Keputusan Menteri Pertanian, 1993).

Produktivitas kentang Indonesia pada tahun 2015 hanya mencapai 18,2 ton ha ${ }^{-1}$ (Kementan, 2016d). Hal ini dapat disebabkan oleh varietas Granola L dan Atlantik menghasilkan adaptasi yang rendah. Oleh karena itu, perlu adanya usaha-usaha untuk memperoleh varietas unggul yang menghasilkan daya hasil tinggi. Salah satu cara untuk memperoleh varietas unggul yaitu melakukan kegiatan pemuliaan tanaman. Pusat Kajian Hortikultura Tropika (PKHT) dan Departemen Agronomi dan Hortikultura (AGH), Institut Pertanian Bogor, telah melakukan berbagai usaha dalam pemuliaan tanaman kentang. PKHT dan Departemen AGH telah merakit genotipegenotipe kentang yang berpotensi menghasilkan produksi tinggi dengan kode PKHT 2, PKHT-3, PKHT-4, PKHT-6,PKHT-9, PKHT-10 dan PKHT-12. Genotipe-genotipe tersebut merupakan genotipe kentang harapan IPB, agar dapat meningkatkan produksi kentang.

Penyebab lain rendahnya produksi kentang di Indonesia adalah rendahnya kualitas dan kuantitas bibit kentang (Aulia et al., 2014). Petani umumnya menggunakan bibit asal umbi yang tidak bersertifikat, tidak jelas turunan dan asal-usulnya. Pengadaan dan distribusi bibit kentang berkualitas belum kontinyu dan memadai. Bibit berkualitas dari umbi sulit didapat petani dan harganya relatif mahal, sehingga petani kentang menanam bibit dari hasil panen sebelumnya. Bibit yang digunakan secara terus menerus dapat menyebabkan rendahnya produksi (Sastrahidayat, 2011). Alternatif teknik perbanyakan yang dapat diaplikasikan petani di lapang perlu dilakukan untuk mengurangi penurunan produksi. Micropropagation dapat dijadikan alternatif perbanyakan (Wattimena et al., 1983). Kentang dapat diperbanyak menggunakan beberapa metode yaitu umbi mikro dan stek. Menurut Levy (1988), planlet dapat dijadikan sumber stek buku tunggal sebagai bahan tanam di lapang. Penelitian ini bertujuan untuk mendapatkan genotipe IPB asal stek buku tunggal dengan keragaan produksi G2 tertinggi dan membandingkan hasil produksi kentang antara tanaman yang berasal dari bahan tanam stek buku tunggal dengan umbi di lapang.

\section{BAHAN DAN METODE}

Penelitian dilaksanakan pada Februari-Juli 2017 di Desa Tambakbaya, Kecamatan Cisurupan dan Desa Margamulya, Kecamatan Cikajang, Kabupaten Garut. Bahan yang digunakan dalam penelitian terdiri atas genotipe PKHT-2, PKHT-3, PKHT-4, PKHT-6, PKHT-9, PKHT-10, PKHT12, Atlantik, Granola, Medians dan Intan. Bahan lain yang digunakan yaitu pupuk kandang ayam, NPK Mutiara 16:16:16, pupuk $\mathrm{KCl}$, pupuk ZA, pupuk TSP, pestisida dan fungisida. Alat yang digunakan yaitu alat budi daya pertanian, alat tulis, timbangan analitik, jangka sorong, label dan alat dokumentasi.

Penelitian terdiri atas dua percobaan. Percobaan pertama tentang keragaan produksi G2 kentang asal stek buku tunggal pada genotipe harapan IPB. Percobaan dilakukan untuk mengetahui keragaan produksi pada genotipe harapan IPB membandingkan dengan varietas komersial. Bahan percobaan yang digunakan terdiri atas bahan tanam stek buku tunggal 
genotipe PKHT-2, PKHT-3, PKHT-4, PKHT-6, PKHT-9, PKHT-10, PKHT-12, Atlantik, Granola, Medians dan Intan. Percobaan dilakukan dengan menggunakan Rancangan Kelompok Lengkap Teracak (RKLT) faktor tunggal yaitu genotipe yang terdiri atas 11 genotipe dengan 3 ulangan, sehingga terdapat 33 satuan percobaan. Setiap satuan percobaan terdapat 20 tanaman dan diambil 10 tanaman sebagai tanaman contoh. Pengamatan percobaan meliputi persen bibit hidup (\%), tinggi tanaman (cm), jumlah daun (helai), jumlah cabang, diameter batang ( $\mathrm{mm})$, panjang umbi $(\mathrm{cm})$, diamter umbi $(\mathrm{mm})$, bobot per umbi $(\mathrm{g})$, jumlah umbi per tanaman (knol), bobot umbi per tanaman (g), dan hasil umbi per hektar (ton ha-1).

Percobaan dua tentang pengaruh interaksi genotipe dan bahan tanam terhadap keragaan produksi. Bahan percobaan yang digunakan adalah bahan tanam stek buku tunggal dan umbi G1 yang sudah pecah dorman bobot $\pm 5 \mathrm{~g} \mathrm{umbi}^{-1}$ dari genotipe PKHT-4, Intan dan Medians. Percobaan dilakukan dengan menggunakan Rancangan Kelompok Lengkap Teracak (RKLT) dengan dua faktor yaitu genotipe dan sumber bahan tanam. Terdapat 3 genotipe dan 2 jenis bahan tanam. Setiap kombinasi diulang 3 kali sehingga terdapat 18 satuan percobaan. Data satuan percobaan bahan tanam asal stek merupakan data yang sama pada percobaan pertama pada genotipe yang sama, sehingga pada percobaan kedua hanya terdapat 9 satuan percobaan. Setiap satuan percobaan terdapat 20 tanaman dan diambil 10 tanaman sebagai tanaman contoh.

Percobaan dua dilakukan untuk melihat pengaruh sumber bahan tanam dan genotipe terhadap beberapa variabel pengamatan. Variabel yang diamati meliputi komponen pertumbuhan di lapang (tinggi tanaman, diameter batang, jumlah cabang dan jumlah daun) dan produksi (jumlah umbi per tanaman, bobot per umbi, bobot per tanaman, hasil per hektar). Data pengamatan yang diperoleh dianalisis dengan menggunakan uji $\mathrm{F}$ pada taraf $\alpha=5 \%$. Jika uji $\mathrm{F}$ menunjukan pengaruh nyata, maka dilakukan uji lanjut dengan DMRT (Duncan Multiple Range Test) pada taraf $\alpha$ $=5 \%$.

\section{HASIL DAN PEMBAHASAN}

\section{Keragaan Produksi Bahan Tanam Stek Buku Tunggal}

Persen bibit hidup beberapa genotipe kentang harapan IPB berada di atas $80 \%$, kecuali PKHT-2. Persen bibit hidup merupakan salah satu indikator daya adaptasi bibit di lapang. Metode yang kurang tepat pada saat pemindahan bibit akan mempengaruhi daya adaptasi tanaman. Media tanam yang pecah saat pindah tanam menyebabkan beberapa akar terputus atau patah, sehingga bibit mengalami cekaman pasca pindah tanam (Santoso et al., 2009). Berdasarkan Tabel 1, genotipe berpengaruh sangat nyata terhadap variabel pengamatan persen bibit hidup, tinggi tanaman, diameter batang, jumlah cabang, dan jumlah daun. Kisaran persen bibit hidup pada genotipe kentang 75,44-100\%. PKHT-6 adalah genotipe yang menghasilkan persen bibit hidup tertinggi yaitu $100 \%$, namun tidak berbeda nyata secara statistik dengan PKHT-9, PKHT-10, PKHT-12, dan Medians.

Tabel 1. Pengaruh genotipe terhadap pertumbuhan dilapang

\begin{tabular}{lccccc}
\hline \multicolumn{1}{c}{ Genotipe } & Bibit hidup $(\%)$ & $\begin{array}{c}\text { Tinggi tanaman } \\
(\mathrm{cm})\end{array}$ & $\begin{array}{c}\text { Diameter batang } \\
(\mathrm{cm})\end{array}$ & $\begin{array}{c}\text { Jumlah cabang } \\
\text { Jumlah daun } \\
(\text { helai })\end{array}$ \\
\hline PKHT-2 & $75,55 \mathrm{~d}$ & $10,33 \mathrm{edf}$ & $0,24 \mathrm{~d}$ & $3,8 \mathrm{bcd}$ & $30,5 \mathrm{c}$ \\
PKHT-3 & $85,42 \mathrm{bcd}$ & $11,59 \mathrm{cde}$ & $0,22 \mathrm{~d}$ & $3,9 \mathrm{bcd}$ & $34,3 \mathrm{bc}$ \\
PKHT-4 & $82,46 \mathrm{~cd}$ & $13,39 \mathrm{~cd}$ & $0,37 \mathrm{c}$ & $2,0 \mathrm{def}$ & $17,8 \mathrm{def}$ \\
PKHT-6 & $100,00 \mathrm{a}$ & $44,03 \mathrm{a}$ & $0,72 \mathrm{a}$ & $8,3 \mathrm{a}$ & $76,5 \mathrm{a}$ \\
PKHT-9 & $98,25 \mathrm{ab}$ & $16,29 \mathrm{c}$ & $0,31 \mathrm{~cd}$ & $2,4 \mathrm{de}$ & $19,8 \mathrm{de}$ \\
PKHT-10 & $89,47 \mathrm{abcd}$ & $27,82 \mathrm{~b}$ & $0,48 \mathrm{~b}$ & $2,9 \mathrm{~cd}$ & $27,3 \mathrm{~cd}$ \\
PKHT-12 & $98,25 \mathrm{ab}$ & $7,05 \mathrm{ef}$ & -- & $0,5 \mathrm{ef}$ & $9,9 \mathrm{efg}$ \\
Atlantik & $80,56 \mathrm{~cd}$ & $10,69 \mathrm{def}$ & $0,24 \mathrm{~d}$ & $0,8 \mathrm{ef}$ & $11,9 \mathrm{efg}$ \\
Granola & $77,77 \mathrm{~d}$ & $5,50 \mathrm{f}$ & -- & $0,2 \mathrm{f}$ & $6,8 \mathrm{~g}$ \\
Intan & $75,44 \mathrm{~d}$ & $27,00 \mathrm{~b}$ & $0,36 \mathrm{c}$ & $4,7 \mathrm{bc}$ & $34,12 \mathrm{bc}$ \\
Medians & $94,74 \mathrm{abc}$ & $25,67 \mathrm{~b}$ & $0,66 \mathrm{a}$ & $4,9 \mathrm{~b}$ & $42,9 \mathrm{~b}$ \\
\hline Uji F & $* *$ & $* *$ & $* *$ & $* *$ & $* *$ \\
\hline
\end{tabular}

Keterangan: Angka-angka pada kolom yang sama yang diikuti oleh huruf yang sama tidak berbeda nyata pada DMRT taraf $\alpha=$ $5 \%, *$ berpengaruh nyata pada taraf $5 \%, * *=$ berpengaruh sangat nyata pada taraf $1 \%$.

Menurut komunikasi pribadi dengan petani, rendahnya persen bibit hidup pada beberapa klon/varietas dapat diakibatkan oleh curah hujan pada saat penanaman. Penanaman dilakukan pada bulan April 2017, curah hujan pada bulan tersebut yaitu $398 \mathrm{~mm}$ (BMKG, 2017). Curah hujan yang dikehendaki pertanaman kentang sekitar 2000-3000 mm tahun ${ }^{-1}$ atau 
sekitar 160-250 mm bulan ${ }^{-1}$ (Kementan, 2011). Curah hujan yang tergolong tinggi pada saat penanaman dan bibit yang belum memiliki sistem perakaran yang kuat dan dalam, mengakibatkan tanaman mudah roboh, tertutupi tanah dan busuk.

Menurut Hidayat (2014), tanaman kentang yang baik untuk dibudidayakan adalah kentang yang tidak terlalu tinggi, sehingga dapat meminimalisasi kemungkinan terjadinya roboh. Menurut Zulkarnain (2016), tinggi tanaman kentang dibagi ke dalam lima tingkatan karakter UPOV (International Union for the Protection of New Varieties of Plants) yaitu sangat pendek (< $44,0 \mathrm{~cm})$, pendek $(44,0-49,9 \mathrm{~cm})$, sedang $(50,0-$ $54,9 \mathrm{~cm})$, tinggi $(55,0-59,9 \mathrm{~cm})$ dan sangat tinggi (> 59,9 cm). Berdasarkan klasifikasi UPOV ini maka tinggi tanaman pada Tabel 1 menunjukan bahwa semua genotipe yang diamati menghasilkan tinggi $<44,0 \mathrm{~cm}$ atau sangat pendek. Genotipe PKHT-6 merupakan genotipe dengan tinggi tanaman pendek, yaitu 44,03 cm.

Menurut Solihati (2016), diameter batang yang besar diharapkan dapat menopang tanaman yang tinggi untuk tumbuh tegak sehingga tanaman tidak mudah rebah. Genotipe PKHT-6 menghasilkan diameter batang terbesar dibanding genotipe lainnya yaitu $7,22 \mathrm{~mm}$, namun secara statistik tidak berbeda nyata dengan varietas pembandingnya yaitu kentang varietas Medians. Genotipe PKHT-3 menghasilkan diameter yang kecil yaitu $2,25 \mathrm{~mm}$, namun tidak berbeda nyata secara statistik dengan genotipe PKHT-2, PKHT-9 dan varietas Atlantik. Genotipe PKHT-12 dan varietas Granola tidak dilakukan pengukuran diameter batang, karena menghasilkan tinggi tanaman kurang dari $10 \mathrm{~cm}$.

Jumlah cabang dan daun pada genotipe PKHT-6 menghasilkan jumlah terbanyak dibandingkan genotipe lain yaitu 8,3 cabang dan 76,5 helai. Kriteria tanaman kentang yang diharapkan petani adalah menghasilkan jumlah cabang yang banyak. Hal ini dapat mendukung peningkatan jumlah daun seiring dengan perkembangan jumlah cabang (Aulia et al., 2014). Banyaknya jumlah daun dapat menghasilkan fotosintat yang maksimal. Jumlah daun terbanyak adalah Genotipe PKHT-6 diikuti Medians, Intan, PKHT-3, PKHT-2, PKHT-10, PKHT-9, PKHT-4, Atlantik, PKHT-12, dan Granola.

Tabel 2. Pengaruh genotipe terhadap pertumbuhan umbi kentan

\begin{tabular}{|c|c|c|c|c|c|}
\hline \multirow{2}{*}{ Genotipe } & \multicolumn{2}{|c|}{ Karakter umbi } & \multicolumn{3}{|c|}{ Bobot per umbi (g) } \\
\hline & Panjang $(\mathrm{cm})$ & Diameter $(\mathrm{cm})$ & Minimum & Maksimum & Rataan \\
\hline PKHT-2 & $0,96 \mathrm{e}$ & $1,71 \mathrm{~d}$ & 0,20 & 18,28 & $3,58 \mathrm{de}$ \\
\hline PKHT-3 & $0,94 \mathrm{e}$ & $1,70 \mathrm{~d}$ & 0,15 & 13,59 & $3,69 \mathrm{~cd}$ \\
\hline PKHT-4 & $2,40 \mathrm{bc}$ & $1,88 \mathrm{c}$ & 0,43 & 64,28 & $5,00 \mathrm{abc}$ \\
\hline РКHT-6 & $2,10 \mathrm{~cd}$ & $1,96 b c$ & 0,32 & 128,32 & $4,92 \mathrm{abc}$ \\
\hline PKHT-9 & $2,42 b$ & $1,84 \mathrm{~cd}$ & 0,58 & 33,27 & $6,28 \mathrm{a}$ \\
\hline PKHT-10 & $2,23 \mathrm{bcd}$ & $1,88 \mathrm{c}$ & 0,37 & 77,25 & $4,63 \mathrm{bc}$ \\
\hline РКHT-12 & $1,93 d$ & $1,49 \mathrm{e}$ & 0,24 & 13,01 & 3,00de \\
\hline Granola & $1,96 \mathrm{~d}$ & $1,26 f$ & 0,08 & 2,88 & $1,78 \mathrm{e}$ \\
\hline Atlantik & $2,05 \mathrm{~d}$ & $1,84 \mathrm{~cd}$ & 0,67 & 18,31 & $4,44 \mathrm{bcd}$ \\
\hline Intan & $2,78 \mathrm{a}$ & $2,26 \mathrm{a}$ & 1,00 & 45,67 & $5,16 a b c$ \\
\hline Medians & $2,25 \mathrm{bcd}$ & $2,05 \mathrm{~b}$ & 1,33 & 111,00 & $5,63 \mathrm{ab}$ \\
\hline Uji F & $* *$ & $* *$ & & & $* *$ \\
\hline
\end{tabular}

Umbi kentang dipanen setelah $80 \%$ tanaman layu (UPOV, 2004). Beberapa genotipe dipanen pada umur 110 HST, kecuali varietas Granola yang dipanen pada 100 HST. Genotipe sangat berpengaruh nyata pada karakter panjang umbi dan rataan bobot per umbi, serta diameter umbi. Rataan bobot per umbi pada genotipe PKHT-9 menghasilkan bobot terbesar yaitu 6,28 g per umbi dengan rataan bobot minimum $0,58 \mathrm{~g}$ dan maksimum 33,27 g. Rataan bobot per umbi genotipe PKHT-9 tidak berbeda nyata secara statistik dengan Medians, Intan, PKHT-4 dan PKHT-6.

Berdasarkan Tabel 3, genotipe PKHT-6 menghasilkan jumlah umbi terbanyak yaitu 21,5 knol per tanaman. PKHT-2 menghasilkan jumlah umbi 13,7 knol terbanyak kedua setelah PKHT-6 dan tidak berbeda nyata dengan PKHT-3, Intan, Medians, PKHT-10 dan PKHT-4. Bobot umbi berkaitan dengan jumlah umbi, namun jumlah umbi yang banyak tidak akan terlalu berarti apabila bobot per satuan umbi bernilai kecil (Zulkarnain, 2016). Jumlah umbi PKHT-2 tergolong banyak, namun genotipe ini menghasilkan bobot per tanaman dan hasil per hektar hanya 45,24 g dan 1,49 ton karena menghasilkan rataan bobot umbi yang kecil dan tidak berbeda nyata dengan PKHT-3, PKHT-12, Atlantik dan Granola.

Medians, Intan, Atlantik dan Granola sebagai varietas pembanding secara berturut-turut menghasilkan hasil per hektar 14,48 ton, 5,51 
ton, 1,40 ton dan 0,10 ton. Hasil umbi kentang varietas pembanding pada penelitian lebih rendah dari potensi hasil yang terdaftar. Hal ini dapat disebabkan karena sumber bahan tanam dan waktu pelaksanaan penelitian saat curah hujan tinggi sehingga kelembaban, suhu, dan lamanya penyinaran kurang maksimal untuk mencapai potensi umbi maksimal. Genotipe PKHT-6 menghasilkan bobot per tanaman dan hasil per hektar tertinggi dibandingkan varietas pembanding maupun genotipe lainnya yaitu $362,56 \mathrm{~g}$ dan 18,32 ton.

Tabel 3. Persentase jumlah umbi hasil grading per tanaman, bobot per tanaman dan hasil per hektar

\begin{tabular}{|c|c|c|c|c|c|c|c|c|c|}
\hline \multirow[b]{2}{*}{ Genotipe } & \multirow{2}{*}{$\begin{array}{c}\text { Jumlah umbi } \\
\text { per tanaman } \\
\quad(\mathrm{knol})\end{array}$} & \multicolumn{6}{|c|}{ Jumlah Umbi (\%) } & \multirow{2}{*}{$\begin{array}{l}\text { Bobot per } \\
\text { tanaman } \\
(\mathrm{g})\end{array}$} & \multirow{2}{*}{$\begin{array}{l}\text { Hasil } \\
\text { per } \\
\text { hektar } \\
\text { (ton) }\end{array}$} \\
\hline & & $X L^{b}$ & $\mathrm{~L}^{\mathrm{b}}$ & $\mathrm{M}^{\mathrm{b}}$ & $S^{b}$ & $\mathrm{XS}^{\mathrm{b}}$ & $X X S^{b}$ & & \\
\hline PKHT-2 & $13,7 \mathrm{~b}$ & -- & -- & -- & 19,37 & $59,94 a$ & $20,69 c$ & $45,24 d$ & $1,49 \mathrm{ef}$ \\
\hline PKHT-3 & $13,3 b$ & -- & -- & -- & 13,83 & $58,35 \mathrm{a}$ & $27,82 \mathrm{bc}$ & $36,81 \mathrm{~d}$ & $1,47 \mathrm{ef}$ \\
\hline PKHT-4 & $10,2 \mathrm{bc}$ & 14,30 & 13,06 & 11,57 & 19,00 & $30,19 d$ & $16,65 \mathrm{c}$ & $86,77 \mathrm{c}$ & 2,74de \\
\hline PKHT-6 & $21,5 \mathrm{a}$ & 14,63 & 8,31 & 13,25 & 20,47 & $29,68 d$ & $13,66 \mathrm{c}$ & $362,56 a$ & $18,32 \mathrm{a}$ \\
\hline РКНТ-9 & $8,4 \mathrm{~cd}$ & 12,76 & -- & 13,39 & 18,84 & $44,23 \mathrm{abcd}$ & $19,29 \mathrm{c}$ & $42,29 \mathrm{~d}$ & 1,92def \\
\hline PKHT-10 & $10,4 b c$ & 16,03 & 11,05 & 13,21 & 15,89 & $34,39 \mathrm{~cd}$ & $13,11 \mathrm{c}$ & $98,35 c$ & $5,14 \mathrm{c}$ \\
\hline РКHT-12 & $6,5 \mathrm{~d}$ & -- & 8,13 & 8,13 & 11,38 & $46,03 \mathrm{abcd}$ & $44,76 \mathrm{ab}$ & $13,30 \mathrm{~d}$ & $0,46 \mathrm{ef}$ \\
\hline Granola & $2,9 \mathrm{e}$ & -- & -- & -- & -- & $53,21 \mathrm{abc}$ & $46,78 \mathrm{a}$ & $1,75 d$ & $0,04 \mathrm{f}$ \\
\hline Atlantik & $5,3 \mathrm{de}$ & -- & -- & -- & 21,89 & $43,72 \mathrm{abcd}$ & $41,69 \mathrm{ab}$ & $24,62 d$ & $0,62 \mathrm{ef}$ \\
\hline Intan & $10,7 b c$ & 10,06 & 10,38 & 13,09 & 26,28 & $37,38 \mathrm{bdc}$ & $9,63 \mathrm{c}$ & $96,50 \mathrm{c}$ & $4,03 \mathrm{~cd}$ \\
\hline Medians & $10.6 \mathrm{bc}$ & 23.47 & 13.00 & 14.78 & 12.41 & $25.45 \mathrm{~d}$ & $16.35 c$ & $253.42 b$ & $8.41 \mathrm{~b}$ \\
\hline Uji F & $* *$ & tn & tn & tn & tn & $*$ & $* *$ & $* *$ & $* *$ \\
\hline Keterangan: & $\begin{array}{l}{ }^{\mathrm{a}} \mathrm{Ukuran} / \mathrm{kelas} \\
\text { umbi }^{-1}, \mathrm{XS}=1 \\
\text { yang sama tida } \\
\text { sangat nyata pa }\end{array}$ & $\mathrm{AL}$ & $40 \mathrm{~g}$ & $\mathrm{mbi}^{-1}$ & $=30-$ & g umbi & $=20-3$ & umbi $^{-1}, \mathrm{~S}$ & $\begin{array}{l}10-20 \mathrm{~g} \\
\text { eh huruf } \\
\text { gengaruh }\end{array}$ \\
\hline
\end{tabular}

Pengaruh Bahan Tanam dan Genotipe di Lapang

Bahan tanam yang digunakan dalam percobaan kedua adalah stek buku tunggal yang merupakan G0 (benih dasar) dan umbi G1 (benih pokok), bahan tanam ditujukan untuk menghasilkan umbi G2 (benih sebar). Stek buku tunggal tanaman kentang merupakan sumber bahan tanam yang berasal dari planlet (benih penjenis). Keuntungan menggunakan perbanyakan dari planlet adalah tanaman transplant seragam dan bebas penyakit umbi (Levy, 1988; Wattimena,1983), hal ini juga tergantung kepada varietas yang ditanam. Peneliti melakukan percobaan kedua dengan menggunakan dua faktor yaitu genotipe dan bahan tanam.

Tabel 4. Pengaruh interaksi bahan tanam dengan genotipe terhadap tinggi tanaman, diameter batang, jumlah cabang dan jumlah daun

\begin{tabular}{lcccccccc}
\hline \multirow{2}{*}{ Genotipe } & \multicolumn{2}{c}{ Tinggi tanaman $(\mathrm{cm})$} & \multicolumn{2}{c}{ Diameter batang $(\mathrm{cm})$} & \multicolumn{2}{c}{ Jumlah cabang } & \multicolumn{2}{c}{ Jumlah daun (helai) } \\
\cline { 2 - 9 } & Stek & Umbi & Stek & Umbi & Stek & Umbi & Stek & Umbi \\
\hline PKHT-4 & $13,39 \mathrm{bB}$ & $56,64 \mathrm{aA}$ & 0,37 & 0,83 & 2,0 & 1,5 & 17,8 & 23,9 \\
Intan & $27,00 \mathrm{aB}$ & $35,55 \mathrm{bA}$ & 0,36 & 0,82 & 4,7 & 2,6 & 34,2 & 32,3 \\
Medians & $25,67 \mathrm{aB}$ & $40,46 \mathrm{bA}$ & 0,66 & 0,98 & 4,9 & 3,4 & 42,9 & 43,8 \\
\hline
\end{tabular}

Keterangan: Angka-angka pada baris yang sama yang diikuti oleh huruf kapital yang sama atau pada kolom yang sama diikuti huruf kecil yang sama terhadap variabel pengamatan yang sama tidak berbeda nyata pada DMRT taraf $\alpha=5 \%$.

Berdasarkan Tabel 4, terdapat interaksi antara bahan tanam dan genotipe pada variabel tinggi tanaman. Tanaman PKHT-4, Intan dan Medians yang berasal dari bahan tanam umbi secara berurutan menghasilkan tinggi $56,64 \mathrm{~cm}$, $40,46 \mathrm{~cm}$, dan $35,55 \mathrm{~cm}$, sedangkan genotipe yang sama asal stek buku tunggal menghasilkan tinggi $13,39 \mathrm{~cm}, 27,00 \mathrm{~cm}$, dan 25,67 cm. Tinggi tanaman varietas Intan dan Medians asal stek lebih tinggi dibandingkan PKHT-4, sebaliknya tanaman PKHT-4 asal umbi menghasilkan tinggi tanaman lebih tinggi dibandingkan Intan dan Medians. Diameter batang PKHT-4, Intan dan Medians asal stek sebesar 3,71 mm, 3,65 mm dan 6,57 mm. Diameter batang PKHT-4, Intan dan Medians asal umbi sebesar $8,29 \mathrm{~mm}, 8,17 \mathrm{~mm}$ dan 9,76 $\mathrm{mm}$. Diameter batang Medians asal stek buku tunggal dan umbi menghasilkan diameter terbesar dibandingkan genotipe lain. Interaksi antara genotipe dan bahan tanam tidak berpengaruh nyata terhadap diameter batang, jumlah daun dan jumlah cabang. 
Tabel 5. Pengaruh interaksi bahan tanam dengan genotipe terhadap persentase jumlah umbi berdasarkan ukuran/kelas umbi

\begin{tabular}{|c|c|c|c|}
\hline \multirow{2}{*}{ Ukuran/kelas ${ }^{\mathrm{a}}$} & \multirow{2}{*}{ Genotipe } & \multicolumn{2}{|c|}{ Jumlah umbi (\%) } \\
\hline & & Stek buku tunggal $^{\mathrm{b}}$ & $\mathrm{Umbi}^{\mathrm{b}}$ \\
\hline \multirow[t]{3}{*}{$\mathrm{XL}$} & PKHT-4 & 14,30 & 32,27 \\
\hline & Intan & 10,06 & 27,45 \\
\hline & Medians & 23,47 & 21,40 \\
\hline \multirow[t]{3}{*}{$\mathrm{L}$} & PKHT-4 & 13,06 & 14,77 \\
\hline & Intan & 10,38 & 14,96 \\
\hline & Medians & 13,00 & 11,56 \\
\hline \multirow[t]{3}{*}{ M } & PKHT-4 & 11,57 & 14,03 \\
\hline & Intan & 13,09 & 22,40 \\
\hline & Medians & 14,78 & 12,97 \\
\hline \multirow[t]{3}{*}{ S } & PKHT-4 & 19,00 & 22,41 \\
\hline & Intan & 26,28 & 11,84 \\
\hline & Medians & 12,41 & 19,63 \\
\hline \multirow[t]{3}{*}{ XS } & PKHT-4 & 30,18 & 16,50 \\
\hline & Intan & 37,38 & 13,89 \\
\hline & Medians & 25,45 & 20,31 \\
\hline \multirow[t]{3}{*}{ XXS } & PKHT-4 & 16,65 & -- \\
\hline & Intan & 9,62 & 14,17 \\
\hline & Medians & 16,35 & 12,08 \\
\hline
\end{tabular}

Keterangan: ${ }^{\mathrm{a}}$ Ukuran/kelas umbi XL $>40 \mathrm{~g} \mathrm{umbi}{ }^{-1}, \quad \mathrm{~L}=30-40 \mathrm{~g}$ umbi $^{-1}, \mathrm{M}=20-30 \mathrm{~g} \mathrm{umbi}^{-1}, \mathrm{~S}=10-20 \mathrm{~g}$ $\mathrm{umbi}^{-1}, \mathrm{XS}=1-10 \mathrm{~g} \mathrm{umbi}^{-1}, \mathrm{XXS}=<1 \mathrm{~g} \mathrm{umbi}^{-1} ;{ }^{\mathrm{b}}$ Angka-angka pada kolom yang sama yang diikuti oleh huruf yang sama tidak berbeda nyata pada DMRT taraf $\alpha=5 \%, *=$ berpengaruh nyata pada taraf $5 \%$, **= berpengaruh sangat nyata pada taraf $1 \%$.

Menurut Wohleb et al. (2014), umbi kentang berperan sebagai organ perbanyakan vegetatif dan mempunyai fungsi sebagai organ penyimpanan karbohidrat dan nutrisi yang membantu dalam pertumbuhan tanaman. Tanaman asal umbi mempunyai cadangan makanan untuk melangsungkan pertumbuhan dan perkembangannya, sehingga dapat tumbuh dan berkembang dengan optimum dibandingkan tanaman asal stek. Tanaman stek buku tunggal memerlukan waktu untuk beradaptasi agar pertumbuhan optimum. Kondisi cuaca di lapang yang berbeda dengan di pembibitan akan menyebabkan cekaman pasca stek buku tunggal pindah tanam. Tanaman stek buku tunggal memerlukan intensitas cahaya dan air yang cukup untuk berfotosintesis setelah pindah tanam. Rendahnya intensitas cahaya karena seringnya hujan pada bulan-bulan penanaman mempengaruhi proses fotosintesis tanaman, sehingga tanaman kentang yang berasal dari bahan tanam stek buku tunggal tidak mampu menghasilkan fotosintat yang cukup untuk melangsungkan pertumbuhan dan perkembangannya. Menurut McNellis dan Deng (1995) cahaya merupakan salah satu faktor penting bagi pertumbuhan dan perkembangan tanaman. Cahaya berperan dominan dalam proses fotosintesis tanaman. Cahaya berperan juga sebagai pengendali, pemicu, dan modulator respons morfogenesis, khususnya pada awal pertumbuhan tanaman.

Menurut Wulandari et al. (2014), semakin baik pertumbuhan tanaman ada kecenderungan akan menghasilkan umbi dengan ukuran yang lebih besar karena produksi tanaman sangat ditentukan pada fase pertumbuhan vegetatif. Berdasarkan Tabel 5, tanaman genotipe kentang asal umbi didominasi oleh ukuran/kelas grading XL ( > 40 g). Persentase jumlah umbi pada genotipe PKHT-4, Intan dan Medians asal umbi yaitu $32,27 \%, 27,45 \%$ dan $21,40 \%$. Tanaman genotipe kentang asal stek buku tunggal didominasi oleh ukuran/kelas grading XS (1-10 g). Persentase jumlah umbi pada genotipe PKHT4, Intan dan Medians asal umbi yaitu 30,18\%, $37,38 \%$ dan $25,45 \%$.

Berdasarkan Tabel 6 interaksi antara bahan tanam dan genotipe tidak berpngaruh nyata terhadap jumlah umbi per tanaman, bobot per umbi dan bobot per tanaman. Tanaman stek batang dari planlet yang ditanam di lapang mampu menghasilkan jumlah umbi 4,3-13,1 knol, sedangkan tanaman asal umbi menghasilkan 3,77,4 knol (Levy, 1988; Solihati, 2016). Jumlah umbi pada penelitian ini tidak berbeda nyata. Jumlah umbi per tanaman PKHT-4, Intan dan Medians asal stek yaitu 9,5 knol, 10,4 knol dan 
10,6 knol, sedangkan asal umbi yaitu 9,3 knol, 10,4 knol dan 10,5 knol.

Berdasarkan Keputusan Menteri Pertanian Republik Indonesia No 20/Kpts/SR.130/IV/ 2014 benih G2 merupakan benih sebar yang dapat langsung digunakan petani untuk produksi umbi konsumsi (Direktorat Perbenihan Hortikultura, 2015). Umbi konsumsi yang diterima dipasaran menghasilkan bobot per umbi > $60 \mathrm{~g}$ (Solihati, 2016). Varietas Medians, Intan, dan PKHT-4 asal umbi (G1) masing-masing menghasilkan rataan bobot per umbi $92,74 \mathrm{~g}, 88,56 \mathrm{~g}$ dan $71,83 \mathrm{~g}$, namun bobot per umbi pada genotipe yang sama asal stek hanya menghasilkan 5,63 g, 5,16 g dan 5,00 g. Genotipe asal umbi (G1) menghasilkan bobot per umbi (G2) yang mampu diterima di pasaran sebagai umbi konsumsi. Karakter bobot umbi yang besar sangat diminati petani karena menghasilkan nilai jual yang tinggi sebagai umbi konsumsi, sebaliknya bobot umbi yang kecil lebih diminati petani sebagai benih. Maka stek buku tunggal di lapang disarankan sebagai bahan tanam untuk perbanyakan benih.

Tabel 6. Pengaruh interaksi bahan tanam dengan genotipe terhadap umbi per tanaman dan hasil umbi

\begin{tabular}{|c|c|c|c|c|c|c|c|c|}
\hline \multirow{2}{*}{$\begin{array}{c}\text { Genotip } \\
\mathrm{e}\end{array}$} & \multicolumn{2}{|c|}{$\begin{array}{l}\text { Jumlah umbi per tanaman } \\
(\mathrm{knol})\end{array}$} & \multicolumn{2}{|c|}{$\begin{array}{l}\text { Bobot per umbi } \\
(\mathrm{g})\end{array}$} & \multicolumn{2}{|c|}{$\begin{array}{l}\text { Bobot per tanaman } \\
(\mathrm{g})\end{array}$} & \multicolumn{2}{|c|}{$\begin{array}{l}\text { Hasil per hektar } \\
\text { (ton) }\end{array}$} \\
\hline & Stek & Umbi & Stek & Umbi & Stek & Umbi & Stek & Umbi \\
\hline PKHT-4 & 9,5 & 9,3 & 5,00 & 71,83 & 86,77 & 296,91 & $2,74 \mathrm{bB}$ & $17,00 \mathrm{aA}$ \\
\hline Intan & 10,4 & 10,4 & 5,16 & 88,56 & 96,50 & 324,25 & $4,01 \mathrm{bB}$ & $13,33 \mathrm{bA}$ \\
\hline Medians & 10,6 & 10,5 & 5,63 & 92,74 & 253,42 & 353,42 & $8,41 \mathrm{aB}$ & $11,39 \mathrm{bA}$ \\
\hline
\end{tabular}

Keterangan : Angka-angka pada baris yang sama yang diikuti oleh huruf kapital yang sama atau pada kolom yang sama diikuti huruf kecil yang sama terhadap variabel pengamatan yang sama tidak berbeda nyata pada DMRT taraf $\alpha=5 \%$.

Tanaman varietas Medians asal umbi menghasilkan bobot per tanaman lebih tinggi yaitu 353,42 g dibandingkan varietas Intan dan PKHT-4. Terdapat interaksi antara bahan tanam dan genotipe terhadap hasil per hektar. Produksi per hektar PKHT-4, Intan dan Medians asal stek lebih rendah dibandingkan asal umbi. Produksi per hektar PKHT-4, Intan dan Medians asal stek yaitu 2,74 ton, 4,01 ton dan 8,41 ton. Medians asal stek menghasilkan hasil per hektar lebih tinggi dibandingkan Intan dan PKHT-4 asal stek. Produksi per hektar PKHT-4, Intan dan Medians asal umbi yaitu 17,00 ton, 13,33 ton dan 11,39 ton. Genotipe PKHT-4 asal umbi menghasilkan hasil per hektar lebih tinggi dibandingkan Intan dan Medians asal umbi.

\section{KESIMPULAN}

Keragaan produksi pada percobaan pertama setiap variabel pengamatan di lapang dipengaruhi oleh genotipe. Faktor genotipe berpengaruh sangat nyata terhadap persen bibit hidup, tinggi tanaman, diameter batang, jumlah cabang, jumlah batang, panjang umbi, rataan bobot per umbi, jumlah umbi per tanaman, bobot per tanaman dan hasil per hektar. Genotipe PKHT-6 menghasilkan produksi tertinggi dibanding genotipe maupun varietas pembanding lainnya yaitu 18,32 ton $\mathrm{ha}^{-1}$.

Ketiga genotipe pada percobaan kedua menggunakan bahan tanam umbi yaitu PKHT-4, Intan dan Medians menghasilkan potensi hasil lebih tinggi dibandingkan dengan tanaman genotipe yang sama asal stek buku tunggal. Terdapat interaksi antara genotipe dengan bahan tanam terhadap tinggi tanaman dan hasil per hektar. Stek buku tunggal disarankan sebagai bahan tanam untuk perbanyakan benih. Tanaman PKHT-4 asal umbi menghasilkan potensi hasil lebih tinggi dibandingkan varietas pembandingnya yaitu 17 ton $\mathrm{ha}^{-1}$.

\section{DAFTAR PUSTAKA}

Aulia, A.L., M. Nawawi, T. Wardiyati. 2014. Uji daya hasil tujuh genotipe tanaman kentang (Solanum Tuberosum L.). Jurnal Produksi Tanaman. 1(1): 514-521.

[BMKG] Badan Meteorologi, Klimatologi, dan Geofisika. 2017. Data Klimatologi untuk Bulan Maret-Juni 2017 di Perkebunan Cisaruni, Garut. BMKG Dramaga, Bogor.

Direktorat Perbenihan Hortikultura. 2015. Standar Operasional Produksi Benih Kentang (Solanum tuberosum L.). Direktorat Jenderal Hortikultura, Kementerian Pertanian, Jakarta.

Hidayat, Y.S. 2014. Karakterisasi morfologi beberapa genotipe kentang (Solanum tuberosum L.) yang dibudidayakan di Indonesia. Skripsi. Institut Pertanian Bogor. Bogor.

[Kementan] Kementerian Pertanian. 2011. Syarat tumbuh kentang. Kementerian Pertanian, Jakarta.

[Kementan] Kementerian Pertanian. 2016a. Konsumsi per Kapita dalam Rumah 
Tangga Setahun menurut Hasil Susenas, 2013-2015. [Internet] [diunduh 2017 Januari 5] tersedia pada http://aplikasi2.pertanian.go.id/konsumsi/t ampil_susenas_kom2_th.php

[Kementan] Kementerian Pertanian. 2016b. Produksi Kentang Menurut Provinis, 2011-2015. [Internet] [diunduh 2017 Desember 18] tersedia pada http://www.pertanian.go.id/Data5tahun/H ortiASEM2015/Produksi\%20Kentang.pdf.

[Kementan] Kementerian Pertanian. 2016c. Luas Panen Kentang Menurut Provinsi, 20112015. [Internet] [diunduh 2017 Januari 9] tersedia pada http://www.pertanian.go.id/Data5tahun/pd f-HORTI2016/1.1LPanen\%20Kentang .pdf.

[Kementan] Kementerian Pertanian. 2016d. Produktivitas Kentang Menurut Provinsi, 2011-2015. [Internet] [diunduh 2017 Desember 18] tersedia pada http://www.pertanian.go.id/Data5tahun/H ortiASEM2015/Produktivitas\%20Kentang .pdf.

Keputusan Menteri Pertanian. 1993. Deskripsi Kentang Varietas Granola L. Kementerian Pertanian, Jakarta. Keputusan Menteri Pertanian. 2000. Deskripsi Kentang Varietas Atlantik. Kementerian Pertanian, Jakarta.

Levy, D. 1988. Propagation of potato by the transfer of transplants of in vitro proliferated shoot cuttings into the field. Scientia Horticulturae. 36: 165-171.

McNellis, T.W., X.W. Deng. 1995. Light control of seedling morphogenetic pattern. The Plant Cell. 7:1749 1761 .

Samadi. 2007. Kentang dan Analisis Usahatani. Kanisius, Yogyakarta.
Santoso, B.B., Hariyadi, B.S. Purwoko. 2009. Pertumbuhan bibit jarak pagar asal biji dan stek pada berbagai macam media pembibitan. Jurnal Ilmiah Budidaya Pertanian. 2: 138-148.

Sastrahidayat, R. 2011. Tanaman Kentang dan Pengendalian Hama Penyakitnya. Universitas Brawijaya Press, Malang.

Solihati, I. 2016. Identifikasi karakter agronomi tiga genotipe kentang (Solanum tuberosum L.) di Banjarnegara. Skripsi. Institut Pertanian Bogor. Bogor.

[UPOV] International Union for the Protection of New Varieties of Plants. 2004. Guidelines for the Conduct of Tests for Distinctness, Uniformity and Stability of Potato (Solanum tuberosum L.).

Wattimena, G., B. McCown, G. Dan Weis. 1983. Comparative field performance of potatoes from microculture. American Potato Jurnal. 60:27-33.

Wohleb, C.H., N.R. Knowles, M.J. Pavek. 2014. Plant growth and development. Dalam: Navarre R. dan Pavek M., (Eds). The Potato: Botany, Production and Uses. CPI Group Ltd, Croydon, CRO 4YY, London.

Wulandari, A.N., S. Heddy, A. Suryanto. 2014. Penggunaan bobot umbi bibit pada peningkatan hasil tanaman kentang (Solanum tuberosum L.) G3 dan G4 varietas Granola. Jurnal Produksi Tanaman. 2(1): 65-72.

Zulkarnain. 2013. Budidaya Tanaman Tropis. Bumi Aksara, Jakarta.

Zulkarnain, D.H. 2016. Uji daya hasil genotipe harapan kentang (Solanum tuberosum L.) IPB di Kabupaten Garut Jawa Barat. Skripsi. Institut Pertanian Bogor. Bogor. 